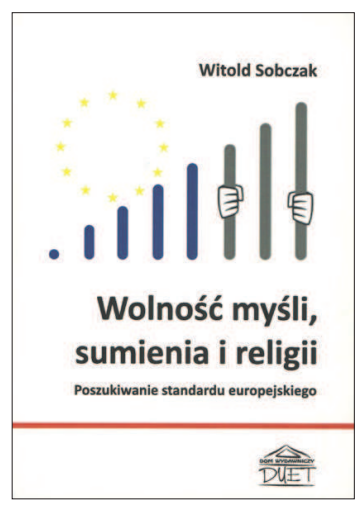

Joanna Taczkowska-Olszewska

(Bydgoszcz)

\section{GRANICE WOLNOŚCI RELIGIJNEJ - DYLEMAT WSPÓŁCZESNYCH DEMOKRACJI}

DOI 10.14746/SEG.2014.9.22

Witold Sobczak, Wolność myśli, sumienia i religii. Poszukiwanie standardu europejskiego, Dom Wydawniczy Duet, Toruń 2013, 789 s.

Okoliczności wskazujące na wyzywające, a niekiedy przestępne, zachowania w odniesieniu do sfery religijności człowieka, a w szczególności czyny wywołujące zarzut znieważenia symboli religijnych, jak również działania zmierzające do dyskryminacji ze względu na wyznawaną religię, stanowią jeden z częściej pojawiających się tematów debaty publicznej. Osią sporu są, z jednej strony, granice koniecznych a zarazem dopuszczalnych interwencji państwa w sferę swobody sumienia i religii, z drugiej zaś strony - granice uzewnętrzniania indywidualnie lub wspólnie $\mathrm{z}$ innymi, publicznie lub prywatnie religii oraz oznaczanie granic ingerencji $\mathrm{w}$ tę sferę w stosunkach prywatnoprawnych. Realizacja swobody sumienia i religii wywołuje zatem wątpliwości zarówno na płaszczyźnie stosunków wertykalnych, jak i horyzontalnych.

Książka Witolda Sobczaka „Wolność myśli, sumienia i religii. Poszukiwanie standardu europejskiego" jest pierwszą i jedyną — jak dotychczas — pozycją naukową, która przy wykorzystaniu wielu metod i narzędzi badawczych oraz sięgając do skrupulatnie zebranych i opracowanych źródeł historycznych oraz źródeł prawa, ujmuje w sposób naukowo-poznawczy problematykę swobody sumienia i religii na tle jej normatywnego wzorca, uwzględniając przy tym ustalenia innych dyscyplin naukowych. Podjęcie tej tematyki nie byłoby możliwe, gdyby nie ogromna wiedza o charakterze interdyscyplinarnym, która pozwoliła autorowi $\mathrm{z}$ dużą śmiałością formułować tezy i hipotezy badawcze, obejmujące zagadnienia historyczne, socjologiczne, politologiczne oraz prawne. W efekcie zrealizowany został zasadniczy cel autora, jakim była analiza zakresu swobody myśli, sumienia i religii zarówno jako zjawiska społecznego, jak i wzorca normatywnego.

Witold Sobczak - jak się wydaje - nie zamierzał ustalać i opisywać tzw. europejskiego standardu wolności sumienia i wyznania. Słusznie bowiem uznał, że standard taki obecnie nie istnieje i trudno przesądzić, czy powstanie on w niedalekiej przyszłości. Autor nie daje jednoznacznej odpowiedzi na pytanie, czy jego 
ustalenie byłoby pożądane. Dostrzega zarazem niebezpieczeństwo wykreowania podwójnego standardu swobody sumienia i religii, co może nastąpić ze względu na odmienny sposób uregulowania tej wolności na gruncie systemu Rady Europy (art. 9 europejskiej Konwencji o ochronie praw człowieka i podstawowych wolności, dalej EKPCz) oraz systemu Unii Europejskiej (art. 10 Karty praw podstawowych UE). Jeśli dostrzec, że generalna teza pracy sprowadzała się do stwierdzenia, że określony w art. 9 EKPCz standard wolności jest zasadniczo zbieżny co do zakresu $\mathrm{z}$ tym, jaki został określony $\mathrm{w}$ innych aktach prawa międzynarodowego, to niewątpliwą zasługą autora jest nie tylko zwrócenie uwagi i wykazanie, że wzorzec taki nie istnieje, ale przede wszystkim odkrycie, że pomimo zbieżnej treści uregulowań zawartych $\mathrm{w}$ różnych aktach prawa międzynarodowego, stanowią one jedynie punkt wyjścia ustanawianych standardów, które mogą się od siebie zasadniczo różnić. Tym bardziej godne podkreślenia wydaje się kolejne ustalenie Witolda Sobczaka, który dochodzi do wniosku, że wyznaczenie zakresu wolności religijnej ,jest procesem dyskursywnym, w którym biorą udział organy władz państwowych, rozmaite instytucje społeczeństwa obywatelskiego, a także kościoły i związki wyznaniowe". Olbrzymi udział w wyznaczaniu standardu wolności myśli, sumienia i religii posiadają - jak zauważa autor — sądy, przy czym największy wpływ na jego określenie przypisać należy Europejskiemu Trybunałowi Praw Człowieka. Organ ten autor uznaje zarazem za wiodący w tej dziedzinie w przyszłości, przypisując mniejsze znaczenie judykatom opierającym się na Karcie praw podstawowych.

Autor nie stroni ani od formułowania odważnych tez i hipotez badawczych, ani od stawiania $w$ centrum uwagi zagadnień zasadniczych, a zarazem niezwykle delikatnych i drażliwych społecznie, jak w szczególności zagadnienie stosunków zachodzących pomiędzy wyznaniową większością a mniejszością. W pracy poszukuje zatem odpowiedzi na jedno z najbardziej nurtujących pytan - czy i na ile mniejszość może narzucać swoje zdanie większości, a także na ile większość musi pogodzić się z tym, że jej zdanie jest nieakceptowane przez mniejszość. Autor nie forsuje żadnej odpowiedzi. Nie znajduje się ona także wśród tez ani hipotez badawczych. Stanowisko to, wskazujące na wymagany w nauce chłodny osąd i neutralność badawczą, należy zaliczyć do jednego z bardziej znaczących atutów pracy. Świadomość wagi poruszanego problemu nakazuje, z jednej strony, zdystansowanie się autorowi, z drugiej jednak strony — zobowiązuje do podjęcia krytycznej analizy wypowiedzi wyrażanych na ten temat zarówno w doktrynie, jak i w orzecznictwie. Witold Sobczak nie omieszkał zatem z całą stanowczości i słusznością podkreślić, że w jednym z najważniejszych orzeczeń wydanych na tle art. 9 EKPCz (Lautsi vs. Włochy), Europejski Trybunał Praw Człowieka prześliznął 
się nad problemem tolerancji religijnej i dylematem, czy jednostka powinna ulec poglądom większości, czy też raczej większość powinna - szanując mniejszość zaakceptować jej żądania i postulaty. Autor dostrzega w orzecznictwie strasburskim szablonowość ujęcia, a nawet brak rozważenia konfliktu interesów występującego na tle styku realizacji swobody sumienia i religii oraz innych wolności. Zauważa również słabość $\mathrm{w}$ warstwie argumentacyjnej orzecznictwa, ujawniającą się na przykład brakiem refleksji nad pojęciem symbolu religijnego.

Warstwa koncepcyjna i struktura pracy, a także jej objętość, rozległość prowadzonych rozważań oraz charakter prowadzonego dyskursu wskazują, że rozprawa stanowi efekt żmudnych poszukiwań, wnikliwych ustaleń oraz drobiazgowych, a przy tym pobudzających poznawczo ustaleń i wniosków. Całość liczy osiem obszernych rozdziałów, przy czym każdy z nich mógłby stanowić odrębne opracowanie sięgające do wiedzy $\mathrm{z}$ innej dyscypliny naukowej. Poszczególne partie są zarazem uporządkowane w taki sposób, że stanowią spójny ciąg, w którym kwestie poprzedzające stanowią asumpt do pogłębionej i bardziej szczegółowej analizy. Zasługą pracy jest zatem zarówno jej terminologiczna precyzja, jak i jednoznaczność formułowanych wniosków i spostrzeżeń. Jasność tę i przejrzystość autor uzyskał dzięki wypracowanej aparaturze pojęciowej oraz świadomości celu badań. Pozwoliło to na uchwycenie i wyjaśnienie problemów terminologicznych w różnych obszarach, mających zarówno naturę ogólną (pojęcie prawa wolnościowego), jak i bardziej szczegółową i zasadniczą dla badanej problematyki (pojęcia wyznania i religii; kościoła i związku wyznaniowego itd.).

Zakres przedmiotowy rozważań, a nade wszystko ich rzeczywista treść nie pozostawiają wątpliwości, że rozprawa Witolda Sobczaka stanowi nie tylko sprawozdanie z wyników prowadzonych badań, ale jest pełnym rozwagi, wyraźnie wyartykułowanym i udokumentowanym stanowiskiem w odniesieniu do różnych pojawiających się w historii koncepcji realizacji swobody sumienia i wyznania w Polsce i na świecie. Szczególnie dużo uwagi autor poświęca chrześcijaństwu oraz kościołom chrześcijańskim, a zwłaszcza Kościołowi katolickiemu i religii rzymskokatolickiej jako dominującej w wielu państwach europejskich, w tym w Polsce. Opisując początki tej religii, sięga do czasów starożytnych, by przeanalizować czynniki i kierunki ekspansji chrześcijaństwa. Przedmiotem zainteresowania jest, jak się wydaje, przede wszystkim ustalenie i ocena stopnia tolerancji, jaką okazywano w przeszłości i okazuje się obecnie względem innych religii. Głęboka wiedza religioznawcza oraz historyczna, i to także z zakresu historii doktryn politycznych, pozwala badaczowi na posłużenie się metodą porównawczą oraz metodą analizy krytycznej w tych partiach pracy, w których rozważaniu poddana zostaje idea tolerancji religijnej. 
Książkę autorstwa Witolda Sobczaka, dostrzegając jej interdyscyplinarny charakter, należy uznać jednak przede wszystkim za rozprawę (studium) z zakresu prawa wyznaniowego. Nawet bowiem $w$ tych fragmentach, w których dominujące wydaje się ujęcie historyczne lub politologiczne, następują — choćby w przypisach - odniesienia do regulacji prawnych. Stanowi to potwierdzenie, że obok uznanej przez autora za zasadniczą dla prowadzonych badań wykładni językowej posłużył się on w wielu miejscach wykładnią historyczną. Sposób ujmowania badanej problematyki pozwala zarazem uznać, że rozprawa, mieszcząc się w granicach prawa wyznaniowego, zarówno poddaje analizie źródła prawa w znaczeniu formalnym, jak i stanowi egzegezę norm prawnych z innych dyscyplin i gałęzi prawa, dla których przedmiotem badania jest zjawisko religijności. Przyjęcie takiej koncepcji pracy pozwoliło Witoldowi Sobczakowi na poszerzenie poszukiwań badawczych o zagadnienia wykraczające poza te przepisy prawa, które ściśle odnoszą się do swobody sumienia i religii. Przedmiotem analizy stały się zatem również zagadnienia dotyczące kolizji z innymi prawami i wolnościami, a także problematyka wychowania dzieci zgodnie z przekonaniami ich rodziców oraz problematyka równoprawności kościołów i związków wyznaniowych oraz - uzupełniająco pojęcia dyskryminacji i obrazy uczuć religijnych. Stanowisko autora nierzadko ma charakter polemiczny. Jak się wydaje, autor nawet oczekuje dyskusji. Dotyczy to zwłaszcza tych fragmentów pracy, w których wyraźnie akcentowane jest ujęcie politologiczne. Analizując czynniki składające się na politykę wyznaniową państwa, badacz zauważa, że państwo polskie przyjęło system aksjologiczny Kościoła katolickiego w jego upolitycznionej i fundamentalistycznej wersji jako wyznacznik naszej tożsamości w zjednoczonej Europie. Wyraża zarazem przekonanie, że partie polityczne realizują model państwa katolickiego posłusznego zaleceniom episkopatu, a Kościół katolicki objął faktycznie rząd dusz w Rzeczypospolitej. Stanowisko to nie wydaje się odpowiadać do końca aktualnej sytuacji Kościoła i zakresowi uzyskiwanych przez niego wpływów. Niemniej zgodzić się trzeba, że tendencje takie były i są obecne w sferze realizacji działań politycznych poszczególnych partii i ugrupowań politycznych.

W warstwie dokumentacyjnej i językowej praca stanowi wzorzec rzetelności i poprawności. Wart podkreślenia jest zarówno język pracy, jak i sposób dokumentowania treści. Adekwatność sformułowań, klarowność rozważań, logika argumentacji sprawiają, że lektura książki musi nawet najwybredniejszemu czytelnikowi sprawiać przyjemność. Szczegółowa dokumentacja, odwołania do literatury krajowej i zagranicznej, a także źródeł historycznych i tekstów prawnych, co ostatecznie wpływa na niezwykle bogatą bibliografię, potwierdza rzetelność prowadzonych badań. Wystarczy wspomnieć, że tylko w odniesieniu do źródeł 
prawa ponadnarodowego analizie poddano ponad setkę aktów normatywnych. Niewątpliwym atutem, obok świetnie udokumentowanych rozważań natury historycznej, są odwołania do orzecznictwa sądów krajowych oraz międzynarodowych organów kontroli sądowej. Autor kończy rozważania sformułowaniem wniosków o charakterze de lege lata, które mogłyby jednak uchodzić, przy założeniu szczególnej postawy interpretatora, za rodzaj postulatów kierowanych pod adresem ugrupowań politycznych, a w dalszej kolejności organów stanowiących prawo.

Zauważyć należy, że problematyka dotycząca zakresu i sposobów realizacji swobody sumienia i religii gwarantowanych w art. 53 Konstytucji, jeśli była dotychczas poddawana badaniom, to wyłącznie na gruncie odrębnych dyscyplin. Badania te miały zazwyczaj wymiar fragmentaryczny, ograniczając się do analizy jednego (np. swobody kultu, statusu związków wyznaniowych, zagadnienia tolerancji religijnej, dyskryminacji) $\mathrm{z}$ wielu zagadnień składających się na naturę swobody sumienia i religii. Inne dyscypliny naukowe, w szczególności socjologia, historia i politologia, jeśli nawet podejmowały tę problematykę, to wyłącznie w zakresie własnych celów i metod badawczych. Zwrócić należy tymczasem uwagę, że częstotliwość występowania w ostatnich latach konfliktów na tle realizacji swobody sumienia i religii nakazywałaby podejrzewać, że sfera wolności religijnej będzie jedną z najbardziej wnikliwie i najczęściej badanych aktywności zarówno przez nauki społeczne, jak i naukę prawa. Było jednak inaczej. Doniosłość problematyki związanej z realizacją wolności sumienia i religii, szczególna jej wrażliwość, a zarazem wielowątkowość i wieloaspektowość wymagająca rozległej wiedzy z wielu dyscyplin naukowych sprawiły, że rzadko była ona poddawana kompleksowej, równocześnie zaś eklektycznej, odwołującej się do różnorodnych perspektyw i metod badawczych analizie. Brak takiej analizy szczególnie uwidocznił się po uchwaleniu i wejściu w życie Konstytucji Rzeczypospolitej Polskiej z dnia 2 kwietnia 1997 roku. Książka Witolda Sobczaka wypełnia lukę, jaka od dawna istniała w nauce w zakresie kompleksowego i wyczerpującego opracowania zagadnień dotyczących realizacji swobody sumienia i wyznania. Stanowi zarazem nowe podejście do problematyki swobody sumienia i wyznania, scalając oraz dokonując rekonstrukcji wyników badań prowadzonych nad religijnością na gruncie różnych dyscyplin naukowych. Aktualność oraz waga dokonanych ustaleń stanowić będą zapewne w przyszłości punkt odniesienia zarówno dla orzecznictwa, jak i doktryny prawa w zakresie, $\mathrm{w}$ jakim przedmiotem ich analizy stają się spory i konflikty wywoływane na tle różnic światopoglądowych i religijnych. 